\title{
Syntheses and Crystal Structures of $\left[\mathrm{Cu}_{3}\left\{\mu-\left(\mathbf{N S P h}_{2}\right)_{2} \mathbf{N}\right\}_{2} \mathbf{C l}_{2}\right]$ and $\left[\mathbf{C u}_{3}\left\{\mu-\left(\mathbf{N S P h}_{2}\right)_{\mathbf{2}} \mathbf{N}\right\}_{\mathbf{2}}\left\{(\mathbf{N S P h})_{2} \mathbf{N}\right\}_{\mathbf{2}}\right] \mathbf{C l}_{\mathbf{2}}$
}

\author{
Takayoshi Fujii, Mihoko Kanno, and Mitsuo Hirata \\ Department of Applied Molecular Chemistry, College of Industrial Technology, Nihon University, \\ Izumi, Narashino, Chiba 275-8575, Japan
}

Correspondence should be addressed to Takayoshi Fujii, fujii.takayoshi@nihon-u.ac.jp

Received 31 August 2009; Accepted 10 November 2009

Academic Editor: J. D. Woollins

Copyright (c) 2010 Takayoshi Fujii et al. This is an open access article distributed under the Creative Commons Attribution License, which permits unrestricted use, distribution, and reproduction in any medium, provided the original work is properly cited.

\begin{abstract}
We have prepared the trinuclear complexes $\left[\mathrm{Cu}_{3}\left\{\mu-\left(\mathrm{NSPh}_{2}\right)_{2} \mathrm{~N}\right\}_{2} \mathrm{Cl}_{2}\right](3)$ and $\left[\mathrm{Cu}_{3}\left\{\mu-\left(\mathrm{NSPh}_{2}\right)_{2} \mathrm{~N}\right\}_{2}\left\{\left(\mathrm{NSPh}_{2}\right)_{2} \mathrm{~N}\right\}_{2}\right] \mathrm{Cl}_{2}(4)$, from the reaction of $\mathrm{CuCl}_{2}$ with $\left\{\mathrm{N}\left(\mathrm{Ph}_{2} \mathrm{SN}\right)\left(\mathrm{Ph}_{2} \mathrm{SNH}\right)\right\}(1)$ and determined their structures by X-ray crystallographic analysis. In both complexes, two monoanions $\mathbf{1}^{-}$chelate the $\mathrm{Cu}$ (II) center in square-planar geometry, whereas the terminal $\mathrm{Cu}$ (II) center is fourcoordinate and a distorted tetrahedron.
\end{abstract}

\section{Introduction}

The chemistry of $\lambda^{6}$-sulfanenitrile, bearing an SN triple bond, shows some interesting and fascinating features. Mews et al. prepared trifluoro- $\lambda^{6}$-sulfanenitrile $\left(\mathrm{F}_{3} \mathrm{~S} \equiv \mathrm{N}\right)$ and its derivatives $\left(F_{2} R S \equiv N\right.$, e.g., $R=\mathrm{Me}_{2} \mathrm{~N}-, F_{2}(\mathrm{O}=) \mathrm{S}=\mathrm{N}-$ ), and investigated their metal coordination chemistry [1$3]$. Recently, we prepared fluoro(diphenyl)- $\lambda^{6}$-sulfanenitrile $\left(\mathrm{Ph}_{2} \mathrm{FS} \equiv \mathrm{N}\right)$ and reported the formation of the various substituted $\lambda^{6}$-sulfanenitriles [4-14]. Among them, new types of $\lambda^{6}$-sulfanenitrile with nitrilo and imino groups (type A) or two nitrilo groups (ndsdsd, type B) at both ends have been shown to complexes as bidentate $N, N^{\prime}$ ligands. For example, the reaction of ndsdsd with $\mathrm{MCl}_{2}(\mathrm{M}=\mathrm{Co}(\mathrm{II})$, $\mathrm{Ni}(\mathrm{II})$, and $\mathrm{Cu}(\mathrm{II}))$ gave the corresponding $\left[\mathrm{MCl}_{2}\right.$ (ndsdsd)] and $\left[\mathrm{M}(\mathrm{ndsdsd})_{2}\right] \mathrm{Cl}_{2}$, and their molecular structures were determined by X-ray crystallographic analysis [15]. The two terminal nitrogen atoms chelate to the metal center to form an eight-membered sulfur-nitrogen ring. We have also performed coordination studies of sulfanenitrile ligands of type A wherein the monoanions reacted with $\mathrm{Ph}_{2} \mathrm{SnCl}_{2}$ to give the corresponding tin-complexes $\left[\mathrm{ClPh}_{2} \mathrm{Sn}\left\{\mathrm{E}\left(\mathrm{Ph}_{2} \mathrm{SN}\right)_{2}\right\}\right](\mathrm{E}$ $=\mathrm{CH}, \mathrm{N})$ in good yields [16]. The crystal structures of both compounds were determined by X-ray crystallographic analysis and showed to consist with a monomeric chelate structure that contains a distorted trigonal bipyramidal tin atom with a nitrogen and chlorine atom in the axial sites. In a further extension of these studies, we examined the reaction of 1 with $\mathrm{CuCl}_{2}$. Herein, we describe the preparation and crystal structure determination of $\left[\mathrm{Cu}_{3}\left\{\mu \text { - }\left(\mathrm{NSPh}_{2}\right)_{2} \mathrm{~N}\right\}_{2} \mathrm{Cl}_{2}\right]$ (3) and $\left[\mathrm{Cu}_{3}\left\{\mu-\left(\mathrm{NSPh}_{2}\right)_{2} \mathrm{~N}\right\}_{2}\left\{\left(\mathrm{NSPh}_{2}\right)_{2} \mathrm{~N}_{2}\right] \mathrm{Cl}_{2}\right.$ (4).
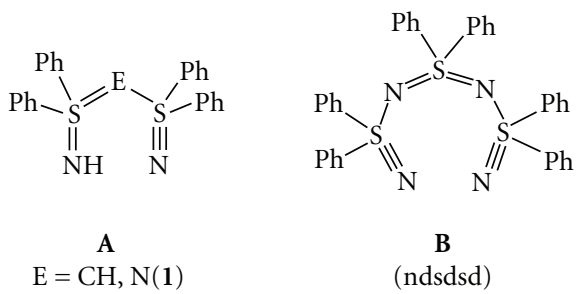

B

(ndsdsd)

\section{Experimental}

2.1. Chemicals and General Methods. All reagents and solvents were obtained commercially and were further purified by general methods when necessary. The single crystal Xray diffraction data were collected with a Rigaku RAXIS RAPID imaging plate using graphite monochromated Mo $\mathrm{K} \alpha$ radiation $(\lambda=0.71075 \AA)$. IR spectra were recorded on a Shimadzu FTIR-8400S spectrometer. Melting points were measured on a Yanaco Mp-J3 melting point apparatus. Elemental analyses were carried out at the Chemical Analysis 
Center of the College of Science and Technology, Nihon University.

2.2. Syntheses. The free ligands $\left\{\mathrm{N}\left(\mathrm{Ph}_{2} \mathrm{SN}\right)\left(\mathrm{Ph}_{2} \mathrm{SNH}\right)\right\}$ (1) was synthesized as described previously [7].

2.2.1. Preparation of $\left[\mathrm{Cu}_{3}\left\{\mu-\left(\mathrm{NSPh}_{2}\right)_{2} N\right\}_{2} \mathrm{Cl}_{4}\right]$ (3) and $\left[\mathrm{Cu}_{3}\left\{\mu-\left(\mathrm{NSPh}_{2}\right)_{2} N\right\}_{2}\left\{\left(\mathrm{NSPh}_{2}\right)_{2} N\right\}_{2}\right] \mathrm{Cl}_{2}$ (4). A solution of 1 (166 mg, $0.4 \mathrm{mmol}$ ) and sodium methoxide (22 $\mathrm{mg}$, $0.4 \mathrm{mmol})$ in methanol $(1.0 \mathrm{~mL})$ was slowly added to a solution of $\mathrm{CuCl}_{2}(81 \mathrm{mg}, 0.6 \mathrm{mmol}$ or $41 \mathrm{mg}, 0.4 \mathrm{mmol})$ in the same solvent $(1.0 \mathrm{~mL})$ at ambient temperature, which started to precipitate a solid within 1 minute. The precipitate was then filtered, washed with methanol, and dried under vacuum at $100^{\circ} \mathrm{C}$ for 24 hours. Crystals suitable for Xray analysis were obtained from metanol-ether (3) and dichloromethane-ether (4).

Data for 3. Green-yellow; Yield 93\%, relative to 1; mp. 221$223^{\circ} \mathrm{C}$ (decomp.); IR (KBr) 3055, 1475, 1445, 1146, 1078, $1065,1024,1009,984 \mathrm{~cm}^{-1}$; UV-vis $\left(\mathrm{MeOH}, \lambda_{\max }, \mathrm{nm}(\varepsilon\right.$, $\left.\left.\mathrm{M}^{-1} \mathrm{~cm}^{-1}\right)\right) 207\left(9.3 \times 10^{4}\right), 407\left(\mathrm{sh}, 3.5 \times 10^{3}\right)$; Anal. Calcd for $\mathrm{C}_{48} \mathrm{H}_{40} \mathrm{Cl}_{4} \mathrm{Cu}_{3} \mathrm{~N}_{6} \mathrm{~S}_{4}$ : C, 49.63; H, 3.47; N, 7.23; Found: C, 49.31; H, 3.38; N, 7.19.

Data for 4. Green; Yield 97\%, relative to 1 ; mp. 151$152^{\circ} \mathrm{C}$ (decomp.); IR (KBr) 3383, 3055, 1473, 1444, 1227, $1159,1067,1007,972 \mathrm{~cm}^{-1}$; UV-vis $\left(\mathrm{MeOH}, \lambda_{\max }, \mathrm{nm}(\varepsilon\right.$, $\left.\left.\mathrm{M}^{-1} \mathrm{~cm}^{-1}\right)\right) 208\left(1.4 \times 10^{5}\right)$, $392\left(\mathrm{sh}, 9.9 \times 10^{3}\right)$; Anal. Calcd for $\mathrm{C}_{96} \mathrm{H}_{88} \mathrm{Cl}_{2} \mathrm{Cu}_{3} \mathrm{~N}_{12} \mathrm{O}_{4} \mathrm{~S}_{8}$ : C, $57.89 ; \mathrm{H}, 4.45 ; \mathrm{N}, 8.44$; Found: C, 57.82; H, 4.15; N, 8.42.

2.3. X-ray Crystallography. Diffraction data were collected with a Rigaku RAXIS RAPID imaging plate using graphite monochromated Mo $\mathrm{K} \alpha$ radiation $(\lambda=0.71075 \AA)$. The data were corrected for Lorentz and polarization effects, and an empirical absorption correction was applied which resulted in transmission factors (see Table 1). The structures 2-4 were solved by the direct method using SHELXS-97 and were refined using SHELXL-97 [17]. Crystal data for $\left[\mathrm{Cu}_{3}\left\{\mu-\left(\mathrm{NSPh}_{2}\right)_{2} \mathrm{~N}\right\}_{2} \mathrm{Cl}_{4}\right](3)$ and $\left[\mathrm{Cu}_{3}\{\mu-\right.$ $\left.\left.\left(\mathrm{NSPh}_{2}\right)_{2} \mathrm{~N}\right\}_{2}\left\{\left(\mathrm{NSPh}_{2}\right)_{2} \mathrm{~N}\right\}_{2}\right] \mathrm{Cl}_{2}(4)$ are given in Table 1.

\section{Results and Discussion}

The addition of an equimolecular amount of $\mathbf{1}$ to $\mathrm{CuCl}_{2}$ in methanol at ambient temperature immediately gave a greenyellow solution and green precipitates. After filtering the precipitates and removing the solvent, the recrystallization of the residue from methanol-ether gave yellow crystals 2. On the other hand, the precipitates were recrystallized from methanol-ether to give green-yellow crystals 3 . The compositions of $\mathbf{2}$ and $\mathbf{3}$ were identified by elemental analysis and IR spectroscopy, and their structures were determined by X-ray crystallographic analysis (Figure 1 and Supplementary Figure S1, in Supplementary Material available online at doi:10.1155/2010/326568). Preliminary experiments indicated that $\mathbf{1}$ acts as the bridging ligands and base to form the

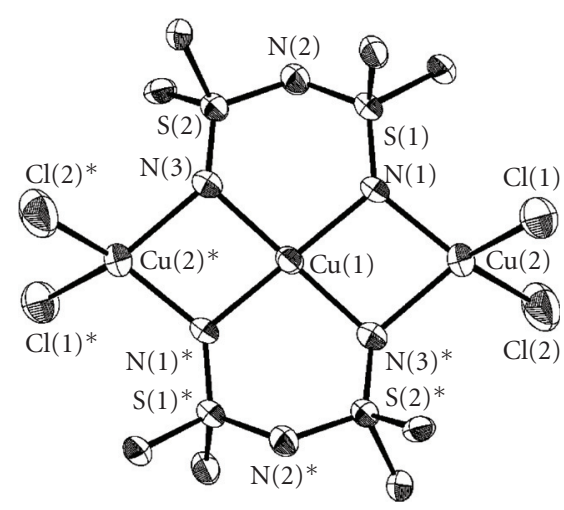

FIGURE 1: ORTEP drawing of 3 (50\% probability thermal ellipsoids; $\mathrm{H}$ and $\mathrm{C}$ atoms (apart from the $\mathrm{C} \alpha$ atoms of the phenyl rings) have been omitted for clarity).

trinuclear complex, $\left[\mathrm{Cu}_{3}\left\{\mu-\left(\mathrm{NSPh}_{2}\right)_{2} \mathrm{~N}_{2} \mathrm{Cl}_{4}\right]\right.$ (3), and protonated compound, $\left\{\mathrm{N}\left(\mathrm{Ph}_{2} \mathrm{SNH}\right)_{2}\right\}_{2} \mathrm{CuCl}_{4}(2)$, respectively, (Scheme 1). Therefore, complexe 3 was prepared effectively and almost quantitatively from the reaction of $\mathbf{1}$ and $\mathrm{CuCl}_{2}$ (1.5 equivalents) in the presence of sodium methoxide as the base in methanol at ambient temperature (Scheme 1). Furthermore, the reaction of 1 and $\mathrm{CuCl}_{2}$ in the ratio 4 : 3 under the above conditions gave the corresponding compound $\left[\mathrm{Cu}_{3}\left\{\mu \text { - }\left(\mathrm{NSPh}_{2}\right)_{2} \mathrm{~N}\right\}_{2}\left\{\left(\mathrm{NSPh}_{2}\right)_{2} \mathrm{~N}\right\}_{2}\right] \mathrm{Cl}_{2}$ (4) almost quantitatively (Scheme 1). Green crystals of 4 suitable for X-ray analysis were obtained by crystallization from dichloromethane-ether at ambient temperature.

In order to confirm the identity of $\left[\mathrm{Cu}_{3}\left\{\mu-\left(\mathrm{NSPh}_{2}\right)_{2} \mathrm{~N}\right\}_{2} \mathrm{Cl}_{4}\right]$ (3) and $\left[\mathrm{Cu}_{3}\{\mu-\right.$ $\left.\left.\left(\mathrm{NSPh}_{2}\right)_{2} \mathrm{~N}\right\}_{2}\left\{\left(\mathrm{NSPh}_{2}\right)_{2} \mathrm{~N}\right\}_{2}\right] \mathrm{Cl}_{2}$ (4), single crystal X-ray structure determinations were carried out. ORTEP drawings of 3 and $\mathbf{4}$ are depicted in Figures 1 and 2. Selected bond lengths and angles for complexes $\mathbf{3}$ and $\mathbf{4}$ are collected in Table 2.

The X-ray structure of 3 shows two independent molecules with nearly identical bond lengths and angles (an ORTEP drawing of one of two independent molecules). The X-ray analysis clearly reveals that it is centrosymmetric trinuclear complex containing two six-membered $\mathrm{CuN}_{3} \mathrm{~S}_{2}$ and two four-membered $\mathrm{Cu}_{2} \mathrm{~N}_{2}$ rings (Figure 1). The two monoanions $\mathbf{1}^{-}$act as a bridging ligand to form the three linearly arranged copper(II) ions with a $\mathrm{Cu} \cdots \mathrm{Cu}$ separation of 3.0377(11) $\AA$. The ligand adopts a boat form conformation wherein the $\mathrm{Cu}(1)$ and the central nitrogen $(\mathrm{N}(2))$ atoms lie 0.365 and $0.489 \AA$, respectively, outside the quasi-plane formed by the $S_{2} \mathrm{~N}_{2}$ of the ring. The terminal nitrogen atoms of the ligand are fixed in a bridging position and the mean value of the terminal $\mathrm{S}-\mathrm{N}$ bond lengths $(1.506 \AA)$ is considerably larger than that of the free ligand $\mathbf{1}$ (mean $1.486 \AA$ ) [8] and is close to that of $\left[\mathrm{CuCl}_{2}\left(\mu-\mathrm{NSPh}_{3}\right)\right]_{2}$ (1.505(4) $\AA$ ) [18]. The internal S-N bond lengths (mean $1.599 \AA)$ and $\mathrm{S}(1)-\mathrm{N}(2)-\mathrm{S}(2)$ angle $\left(118.1(3)^{\circ}\right)$ are close to those of the free ligand 1 (S-N; mean $1.615 \AA$, S-N-S; $\left.117.5(1)^{\circ}\right)[8]$. The central $\mathrm{Cu}(\mathrm{II})$ atom adopts a squareplanar geometry, being linked to four nitrogen atoms $(\mathrm{N}(1)$, 


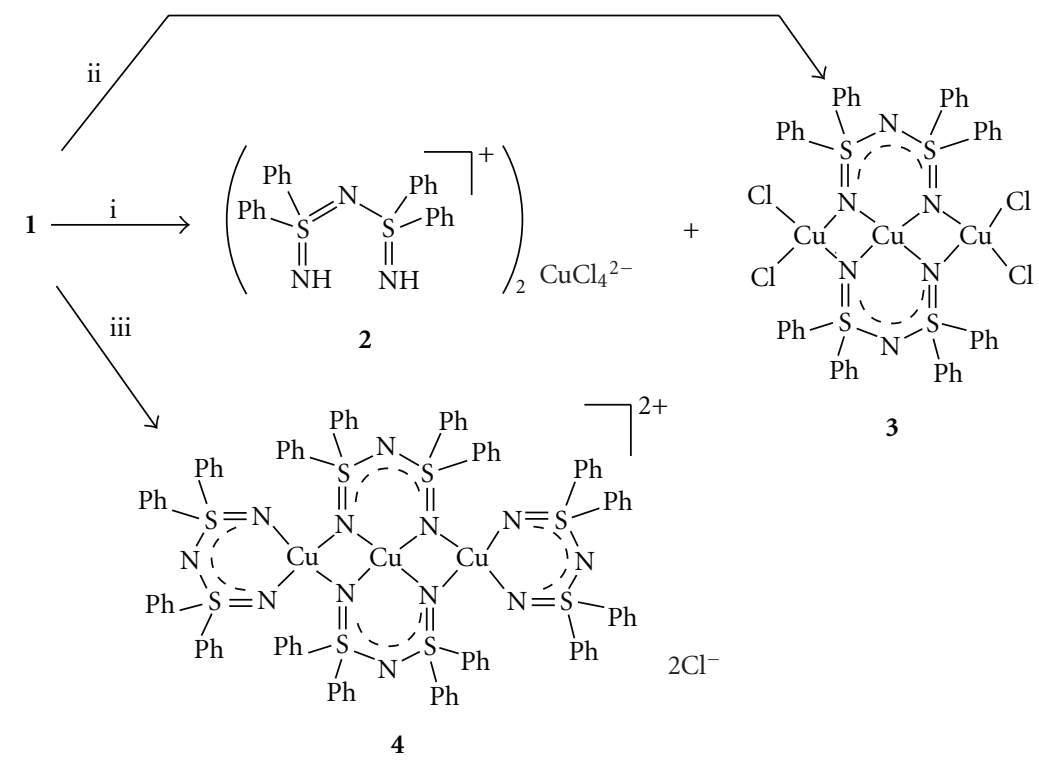

Scheme 1: (i) $\mathrm{CuCl}_{2}$ (1.0 equiv.), $\mathrm{MeOH}$, r.t.; (ii) $\mathrm{CuCl}_{2}$ (1.5 equiv.), $\mathrm{MeONa}, \mathrm{MeOH}$, r.t.; (iii) $\mathrm{CuCl}_{2}$ (0.75 equiv.), $\mathrm{MeONa}, \mathrm{MeOH}$, r.t.

Table 1: Crystallographic Data for Compounds 3 and 4.

\begin{tabular}{|c|c|c|}
\hline & 3 & $4 \cdot 4 \mathrm{H}_{2} \mathrm{O}$ \\
\hline Formula & $\mathrm{C}_{96} \mathrm{H}_{80} \mathrm{Cl}_{8} \mathrm{Cu}_{6} \mathrm{~N}_{12} \mathrm{~S}_{8}$ & $\mathrm{C}_{96} \mathrm{H}_{88} \mathrm{Cl}_{2} \mathrm{Cu}_{3} \mathrm{~N}_{12} \mathrm{O}_{4} \mathrm{~S}_{8}$ \\
\hline Fw & 2323.04 & 1991.87 \\
\hline Cryst size (mm) & $0.23 \times 0.22 \times 0.06$ & $0.66 \times 0.29 \times 0.28$ \\
\hline $\operatorname{Temp}(\mathrm{K})$ & $296(2)$ & $296(2)$ \\
\hline$\lambda(\AA)$ & 0.71075 & 0.71075 \\
\hline Cryst syst & triclinic & triclinic \\
\hline Space group & P-1 & P-1 \\
\hline$a(\AA)$ & $9.294(4)$ & $13.527(6)$ \\
\hline$b(\AA)$ & $14.015(5)$ & $15.760(6)$ \\
\hline$c(\AA)$ & $18.792(6)$ & $16.493(6)$ \\
\hline$\alpha(\mathrm{deg})$ & $93.941(12)$ & $60.552(14)$ \\
\hline$\beta(\operatorname{deg})$ & $93.138(13)$ & $64.828(14)$ \\
\hline$\gamma(\operatorname{deg})$ & $94.280(12)$ & $88.128(15)$ \\
\hline$V\left(\AA^{3}\right)$ & $2430.7(14)$ & $2700.9(17)$ \\
\hline$Z$ & 1 & 1 \\
\hline$\rho_{c}\left(\mathrm{Mg} / \mathrm{m}^{3}\right)$ & 1.587 & 1.220 \\
\hline$\mu\left(\mathrm{mm}^{-1}\right)$ & 1.734 & 0.839 \\
\hline$F(000)$ & 1178 & 1021 \\
\hline$T_{\min } / T_{\max }$ & $0.6912 / 0.9031$ & $0.6073 / 0.7989$ \\
\hline$\theta$ range/deg & $3.00-27.48$ & $3.01-27.48$ \\
\hline Reflns collcd & 23995 & 26115 \\
\hline Indp reflns & 10973 & 12146 \\
\hline$R_{\text {int }}$ & 0.096 & 0.04 \\
\hline Data/restrains/params & $10973 / 0 / 589$ & $12146 / 0 / 565$ \\
\hline $\begin{array}{l}R_{1}, w R_{2} \\
(I>2 \sigma[I])\end{array}$ & $0.0688,0.1074$ & $0.0683,0.1961$ \\
\hline$R_{1}, w R_{2}$ (all data) & $0.1542,0.1337$ & $0.1110,0.2293$ \\
\hline $\mathrm{GOF} / \mathrm{F}^{2}$ & 1.024 & 1.018 \\
\hline
\end{tabular}


TABLE 2: Selected Bond Lenghts ( $\AA$ ) and angles (deg) Compounds 3 and 4.

\begin{tabular}{|c|c|c|c|}
\hline \multicolumn{4}{|c|}{3} \\
\hline $\mathrm{Cu}(1)-\mathrm{N}(1)$ & $1.962(4)$ & $\mathrm{Cu}(2)-\mathrm{N}(3)^{*}$ & $2.079(5)$ \\
\hline $\mathrm{Cu}(1)-\mathrm{N}(3)$ & $1.990(4)$ & $\mathrm{S}(1)-\mathrm{N}(1)$ & $1.508(4)$ \\
\hline $\mathrm{Cu}(2)-\mathrm{Cl}(1)$ & $2.227(2)$ & $\mathrm{S}(1)-\mathrm{N}(2)$ & $1.601(5)$ \\
\hline $\mathrm{Cu}(2)-\mathrm{Cl}(2)$ & $2.196(2)$ & $\mathrm{S}(2)-\mathrm{N}(2)$ & $1.597(5)$ \\
\hline $\mathrm{Cu}(2)-\mathrm{N}(1)$ & $1.975(4)$ & $\mathrm{S}(2)-\mathrm{N}(3)$ & $1.503(4)$ \\
\hline $\mathrm{N}(1)-\mathrm{Cu}(1)-\mathrm{N}(3)$ & $97.50(18)$ & $\mathrm{N}(2)-\mathrm{S}(2)-\mathrm{N}(3)$ & $119.0(2)$ \\
\hline $\mathrm{N}(1)-\mathrm{Cu}(1)-\mathrm{N}(3)^{*}$ & $82.50(18)$ & $\mathrm{Cu}(1)-\mathrm{N}(1)-\mathrm{Cu}(2)$ & $100.99(19)$ \\
\hline $\mathrm{Cl}(1)-\mathrm{Cu}(2)-\mathrm{Cl}(2)$ & $101.58(8)$ & $\mathrm{Cu}(1)-\mathrm{N}(1)-\mathrm{S}(1)$ & $124.8(3)$ \\
\hline $\mathrm{Cl}(1)-\mathrm{Cu}(2)-\mathrm{N}(1)$ & $104.63(15)$ & $\mathrm{Cu}(2)-\mathrm{N}(1)-\mathrm{S}(1)$ & $132.8(3)$ \\
\hline $\mathrm{Cl}(1)-\mathrm{Cu}(2)-\mathrm{N}(3)^{*}$ & $132.08(15)$ & $S(1)-N(2)-S(2)$ & $118.1(3)$ \\
\hline $\mathrm{Cl}(2)-\mathrm{Cu}(2)-\mathrm{N}(1)$ & 138.61(17) & $\mathrm{Cu}(1)-\mathrm{N}(3)-\mathrm{Cu}(2)^{*}$ & $96.55(18)$ \\
\hline $\mathrm{Cl}(2)-\mathrm{Cu}(2)-\mathrm{N}(3)^{*}$ & $105.00(15)$ & $\mathrm{Cu}(1)-\mathrm{N}(3)-\mathrm{S}(2)$ & $123.8(3)$ \\
\hline $\mathrm{N}(1)-\mathrm{Cu}(2)-\mathrm{N}(3)^{*}$ & $79.95(18)$ & $\mathrm{Cu}(2) *-\mathrm{N}(3)-\mathrm{S}(2)$ & $131.9(3)$ \\
\hline $\mathrm{N}(1)-\mathrm{S}(1)-\mathrm{N}(2)$ & $116.5(3)$ & & \\
\hline \multicolumn{4}{|c|}{4} \\
\hline $\mathrm{Cu}(1)-\mathrm{N}(1)$ & $1.966(4)$ & $\mathrm{S}(1)-\mathrm{N}(2)$ & $1.590(3)$ \\
\hline $\mathrm{Cu}(1)-\mathrm{N}(3)$ & $1.976(3)$ & $\mathrm{S}(2)-\mathrm{N}(2)$ & $1.597(3)$ \\
\hline $\mathrm{Cu}(2)-\mathrm{N}(1)^{*}$ & $2.014(3)$ & $\mathrm{S}(2)-\mathrm{N}(3)$ & $1.480(4)$ \\
\hline $\mathrm{Cu}(2)-\mathrm{N}(3)$ & $2.012(3)$ & $\mathrm{S}(3)-\mathrm{N}(4)$ & $1.472(4)$ \\
\hline $\mathrm{Cu}(2)-\mathrm{N}(4)$ & $1.915(4)$ & $\mathrm{S}(3)-\mathrm{N}(5)$ & $1.590(4)$ \\
\hline $\mathrm{Cu}(2)-\mathrm{N}(6)$ & $1.913(4)$ & $\mathrm{S}(4)-\mathrm{N}(5)$ & $1.586(4)$ \\
\hline $\mathrm{S}(1)-\mathrm{N}(1)$ & $1.489(3)$ & $\mathrm{S}(4)-\mathrm{N}(6)$ & $1.478(4)$ \\
\hline $\mathrm{N}(1)-\mathrm{Cu}(1)-\mathrm{N}(3)$ & $97.50(14)$ & $\mathrm{N}(5)-\mathrm{S}(4)-\mathrm{N}(6)$ & $123.5(2)$ \\
\hline $\mathrm{N}(1)-\mathrm{Cu}(1)-\mathrm{N}(3)^{*}$ & $82.50(14)$ & $\mathrm{Cu}(1)-\mathrm{N}(1)-\mathrm{Cu}(2)^{*}$ & $98.69(15)$ \\
\hline $\mathrm{N}(1)^{*}-\mathrm{Cu}(2)-\mathrm{N}(3)$ & $80.42(14)$ & $\mathrm{Cu}(1)-\mathrm{N}(1)-\mathrm{S}(1)$ & $126.42(19)$ \\
\hline $\mathrm{N}(1)^{*}-\mathrm{Cu}(2)-\mathrm{N}(4)$ & $143.23(19)$ & $\mathrm{Cu}(2) *-\mathrm{N}(1)-\mathrm{S}(1)$ & $133.5(2)$ \\
\hline $\mathrm{N}(1)^{*}-\mathrm{Cu}(2)-\mathrm{N}(6)$ & $100.69(15)$ & $S(1)-N(2)-S(2)$ & $119.0(2)$ \\
\hline $\mathrm{N}(3)-\mathrm{Cu}(2)-\mathrm{N}(4)$ & $100.60(16)$ & $\mathrm{Cu}(1)-\mathrm{N}(3)-\mathrm{Cu}(2)$ & $98.39(15)$ \\
\hline $\mathrm{N}(3)-\mathrm{Cu}(2)-\mathrm{N}(6)$ & $143.14(19)$ & $\mathrm{Cu}(1)-\mathrm{N}(3)-\mathrm{S}(2)$ & $126.4(2)$ \\
\hline $\mathrm{N}(4)-\mathrm{Cu}(2)-\mathrm{N}(6)$ & $99.65(16)$ & $\mathrm{Cu}(2)-\mathrm{N}(3)-\mathrm{S}(2)$ & $133.9(2)$ \\
\hline $\mathrm{N}(1)-\mathrm{S}(1)-\mathrm{N}(2)$ & $118.63(18)$ & $\mathrm{Cu}(2)-\mathrm{N}(4)-\mathrm{S}(3)$ & $125.5(2)$ \\
\hline $\mathrm{N}(2)-\mathrm{S}(2)-\mathrm{N}(3)$ & 118.64(18) & $\mathrm{S}(3)-\mathrm{N}(5)-\mathrm{S}(4)$ & $118.6(2)$ \\
\hline $\mathrm{N}(4)-\mathrm{S}(3)-\mathrm{N}(5)$ & $123.3(2)$ & $\mathrm{Cu}(2)-\mathrm{N}(6)-\mathrm{S}(4)$ & $125.2(2)$ \\
\hline
\end{tabular}

The atom labeling scheme is shown in Figure 1 and 2.

$\mathrm{N}(3), \mathrm{N}(1)^{*}$, and $\left.\mathrm{N}(3)^{*}\right)$ of ligand $\mathbf{1}^{-}$. The bond angles around the terminal $\mathrm{Cu}(\mathrm{II})$ atom with two nitrogen and two chlorine atoms span the range of 79.95(18)-138.61(17) ${ }^{\circ}$, substantially deviating from the ideal tetrahedral angle. The dihedral angle of $63.06^{\circ}$ between the $\mathrm{N}(1)-\mathrm{Cu}(2)-\mathrm{N}(3)$ and $\mathrm{Cl}(1)-\mathrm{Cu}(2)-\mathrm{Cl}(2)$ planes shows significant deviation from the ideal $90^{\circ}$ for a tetrahedral arrangement. The bond lengths of $\mathrm{Cu}-\mathrm{N}(1.962(5)-2.079(5) \AA$; mean $2.002 \AA)$ and $\mathrm{Cu}(2)-\mathrm{Cl}(2.196(2)-2.227(2) \AA$; mean $2.212 \AA)$ in 3 are similar to those of $\left[\mathrm{CuCl}_{2}\left(\mu-\mathrm{NSPh}_{3}\right)\right]_{2}(\mathrm{Cu}-\mathrm{N}$; mean $2.016 \AA, \mathrm{Cu}-\mathrm{Cl}$; mean $2.217 \AA[18]$.

The structure of 4 consists of a separated $\left[\mathrm{Cu}_{3}\{\mu\right.$ $\left.\left(\mathrm{NSPh}_{2}\right)_{2} \mathrm{~N}\right\}_{2}\left\{\left(\mathrm{NSPh}_{2}\right)_{2} \mathrm{~N}_{2}\right]^{2+}$ cation, two $\mathrm{Cl}^{-}$anions, and four water molecules. The cation moiety contains a square-plannar central $\mathrm{Cu}$ (II) and two distorted tetrahedral $\mathrm{Cu}(\mathrm{II})$ atoms (Figure 2). The $\mathrm{Cu}(1) \cdots \mathrm{Cu}(2)$ distance is 3.0194(13) A. Although the conformation of the bridging ligand (the $\mathrm{Cu}-\mathrm{N}$ bond lengths in the four-membered $\mathrm{Cu}_{2} \mathrm{~N}_{2}$ 


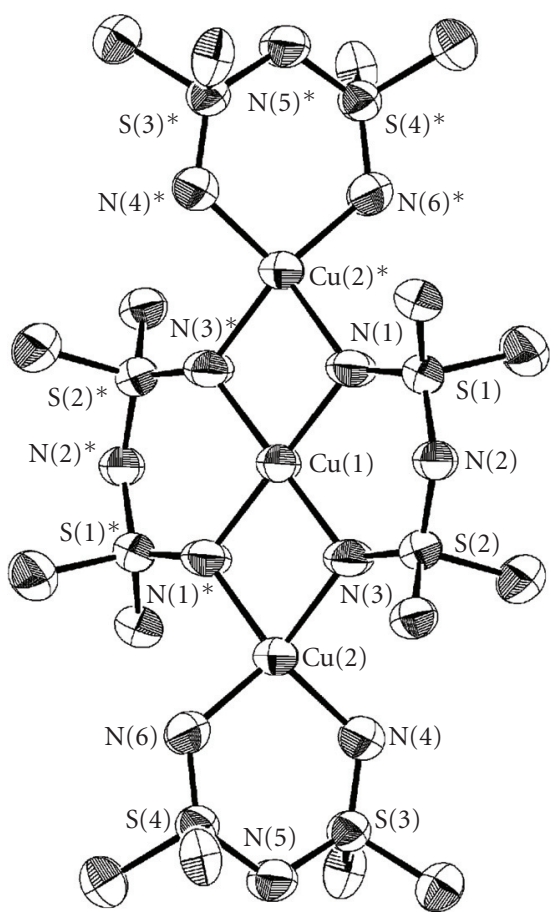

FIgURE 2: ORTEP drawing of 4 (50\% probability thermal ellipsoids; $\mathrm{H}, \mathrm{C}$ atoms (apart from the $\mathrm{C} \alpha$ atoms of the phenyl rings), two chloride anions, and uncoordinated water molecules have been omitted for clarity).

ring are 1.966(4)-2.014(3) $\AA$; mean $1.992 \AA$ ) is similar to that of 3 , the bidentate ligand adopts a twist boat conformation (the $\mathrm{Cu}(2)-\mathrm{N}$ bond lengths in the six-membered $\mathrm{Cu}(2) \mathrm{N}_{3} \mathrm{~S}_{2}$ ring are 1.913(3) and 1.915(3) $\AA$, respectively). The terminal and internal $\mathrm{S}-\mathrm{N}$ bond lengths of the bidentate ligand are slightly shorter than those of the corresponding bridging ligand.

\section{Conclusions}

In summary, we have demonstrated the formation of new types of $\lambda^{6}$-sulfanenitrile-copper(II) complexes, $\quad\left[\mathrm{Cu}_{3}\left\{\mu-\left(\mathrm{NSPh}_{2}\right)_{2} \mathrm{~N}\right\}_{2} \mathrm{Cl}_{2}\right] \quad(3) \quad$ and $\quad\left[\mathrm{Cu}_{3}\{\mu-\right.$ $\left.\left.\left(\mathrm{NSPh}_{2}\right)_{2} \mathrm{~N}\right\}_{2}\left\{\left(\mathrm{NSPh}_{2}\right)_{2} \mathrm{~N}\right\}_{2}\right] \mathrm{Cl}_{2}$ (4), and determined their molecular structures. As magnetic orbital interactions between the copper ions in many multinuclear systems result in ferromagnetic coupling, further investigation of the chemistry of our trinuclear system including the magnetic properties is now in progress.

\section{Acknowledgments}

This work was partially supported by a Grants-in-Aid for Scientific Research (no. 16750030 and 19550051) from the Ministry of Education, Culture, Sports, Science and Technology of Japan and supported by a grant from High Technology Research Center, College of Industrial Technology, Nihon University.

\section{References}

[1] O. Glemser and R. Mews, "Chemistry of thiazyl fluoride (NSF) and thiazyl trifluoride $\left(\mathrm{NSF}_{3}\right)$ : a quarter century of sulfur-nitrogen-fluorine chemistry," Angewandte Chemie International Edition, vol. 19, no. 11, pp. 883-899, 1980.

[2] U. Behrens, E. Lork, J. Petersen, A. Waterfeld, and R. Mews, "Thiazyltrifluoride $\mathrm{NSF}_{3}$ and thiazyldifluoridedimethylamide $\mathrm{NSF}_{2} \mathrm{NMe}_{2}$ : ligands in organometallic chemistry," Zeitschrift für Anorganische und Allgemeine Chemie, vol. 623, no. 10, pp. 1518-1524, 1997.

[3] R. Mews, E. Lork, P. G. Watson, and B. Görtler, "Coordination chemistry in and of sulfur dioxide," Coordination Chemistry Reviews, vol. 197, no. 1, pp. 277-320, 2000.

[4] R. Mews, T. Borrmann, R. Hoppenheit, et al., "Fluorothiazynes, 50 years old and still exciting: electrophilic attack at the thiazyl nitrogen of $\mathrm{NSF}_{2} \mathrm{NS}(\mathrm{O}) \mathrm{F}_{2}$," Journal of Fluorine Chemistry, vol. 125, no. 11, pp. 1649-1655, 2004.

[5] T. Yoshimura, K. Hamada, M. Imado, et al., "First preparation and X-ray crystallographic structure determination of $S, S, S$ triphenylthiazyne," The Journal of Organic Chemistry, vol. 62, no. 12, pp. 3802-3803, 1997.

[6] T. Yoshimura, M. Ohkubo, T. Fujii, et al., "Synthesis, structure, and thermolysis mechanism of S-alkoxythiazynes," Bulletin of the Chemical Society of Japan, vol. 71, no. 7, pp. 1629-1637, 1998.

[7] T. Yoshimura, T. Fujii, S. Murotani, et al., "The structures of $\left[\mathrm{Ph}_{2} \mathrm{XS}-\mathrm{N}-\mathrm{SPh}_{2} \mathrm{NH}\right]^{+}$cations $(\mathrm{X}=\mathrm{NH}, \mathrm{O})$," Journal of Organometallic Chemistry, vol. 611, no. 1-2, pp. 272-279, 2000.

[8] T. Fujii, T. Fujimori, S. Miyoshi, S. Murotani, M. Ohkubo, and T. Yoshimura, "The structures of diphenyl(diphenylsulfimido) (nitrido)sulfur(VI) and diphenyl(diphenylsulfodiimido)(nitrido)sulfur( $\mathrm{VI}), \mathrm{Ph}_{2}(\mathrm{X}) \mathrm{S}=\mathrm{N}-\left(\mathrm{Ph}_{2}\right) \mathrm{S} \equiv \mathrm{N}(\mathrm{X}=$ lone pair, NH)," Heteroatom Chemistry, vol. 12, no. 4, pp. 263-268, 2001.

[9] T. Fujii, A. Itoh, K. Hamata, and T. Yoshimura, "First preparation and crystal structure of heterocyclic $\lambda^{6}$ sulfanenitrile, 2,2' -biphenylylene(phenyl)- $\lambda^{6}$-sulfanenitrile," Tetrahedron Letters, vol. 42, no. 30, pp. 5041-5043, 2001.

[10] T. Fujii, T. Suzuki, T. Sato, E. Horn, and T. Yoshimura, "Synthesis, structure, and reactivity of iminosulfonium ylides bearing an $\alpha$-carbonyl group," Tetrahedron Letters, vol. 42 , no. 35, pp. 6151-6154, 2001.

[11] T. Fujii, T. Ikeda, T. Mikami, T. Suzuki, and T. Yoshimura, "Synthesis and structure of (MeN) $\mathrm{Ph}_{2} \mathrm{~S}=\mathrm{C}=\mathrm{SPh}_{2}(\mathrm{NMe})$," Angewandte Chemie International Edition, vol. 41, no. 14, pp. 2576-2578, 2002.

[12] T. Fujii, S. Asai, T. Okada, W. Hao, H. Morita, and T. Yoshimura, "A new method for the preparation of fluoro$\lambda^{6}$-sulfanenitriles: reaction of sulfimides with selectfluor ${ }^{\mathrm{TM}}$," Tetrahedron Letters, vol. 44, no. 33, pp. 6203-6205, 2003.

[13] T. Fujii, M. Kanno, M. Hirata, T. Fujimori, and T. Yoshimura, "Synthesis and properties of $\mathrm{Ph}_{2} \mathrm{~S}\left(=\mathrm{N}-\left(\mathrm{Ph}_{2}\right) \mathrm{S} \equiv \mathrm{N}\right)_{2}$," Inorganic Chemistry, vol. 44, no. 24, pp. 8653-8655, 2005.

[14] T. Fujii, T. Takano, S. Asai, H. Morita, M. Hirata, and T. Yoshimura, "10-Oxo-10H-5 $\lambda^{4}, 10 \lambda^{4}$-thianthren-5-ylideneamine as a probe for stereochemistry in the formation and amination of fluoro- $\lambda^{6}$-sulfanenitriles," Tetrahedron, vol. 62, no. 41, pp. 9622-9627, 2006. 
[15] T. Fujii, M. Kanno, M. Hirata, T. Nakahodo, T. Wakahara, and T. Akasaka, "Synthesis and characterization of $\mathrm{Co}(\mathrm{II})$, $\mathrm{Ni}(\mathrm{II})$, and $\mathrm{Cu}$ (II) complexes containing an eight-membered disulfanenitrile chelating ring," Inorganica Chimica Acta, vol. 361, no. 8, pp. 2540-2546, 2008.

[16] T. Fujii, S. Iwata, M. Hirata, et al., "Syntheses and crystal structures of $\left[\mathrm{ClPh}_{2} \mathrm{Sn}\left\{\mathrm{E}\left(\mathrm{Ph}_{2} \mathrm{SN}\right)_{2}\right\}\right](\mathrm{E}=\mathrm{CH}, \mathrm{N})$," Phosphorus, Sulfur and Silicon and the Related Elements. In press.

[17] G. M. Sheldrick, "A short history of SHELX," Acta Crystallographica Section A, vol. 64, no. 1, pp. 112-122, 2008.

[18] T. Yoshimura, T. Fujii, and H. Dai, "Synthesis and crystal structures of $\left[\mathrm{CuCl}_{2}\left(\mu-\mathrm{NSPh}_{3}\right)\right]_{2}$ and $\left[\mathrm{CuCl}_{2}\left(\mathrm{Ph}_{3} \mathrm{SN}\right)_{2}\right]$ : novel copper complexes bearing organic $\lambda^{6}$-sulfanenitrile as ligand," Chemistry Letters, vol. 31, no. 10, pp. 1000-1001, 2002. 


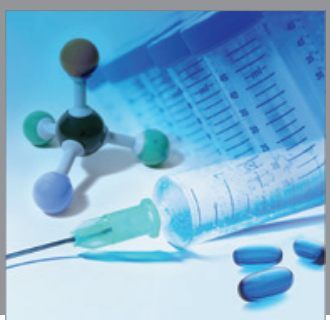

International Journal of

Medicinal Chemistry

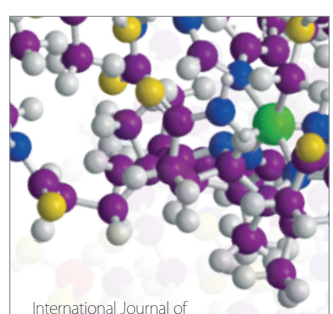

Carbohydrate Chemistry

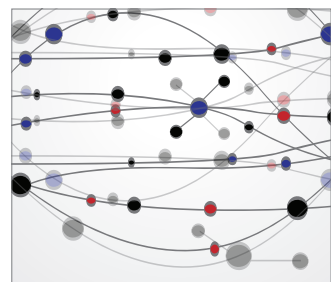

The Scientific World Journal
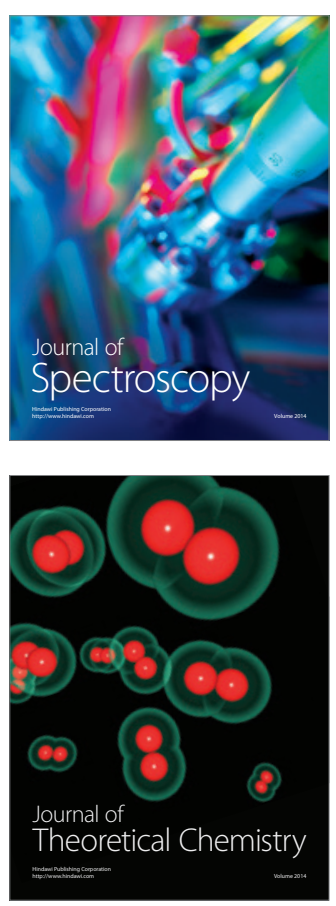
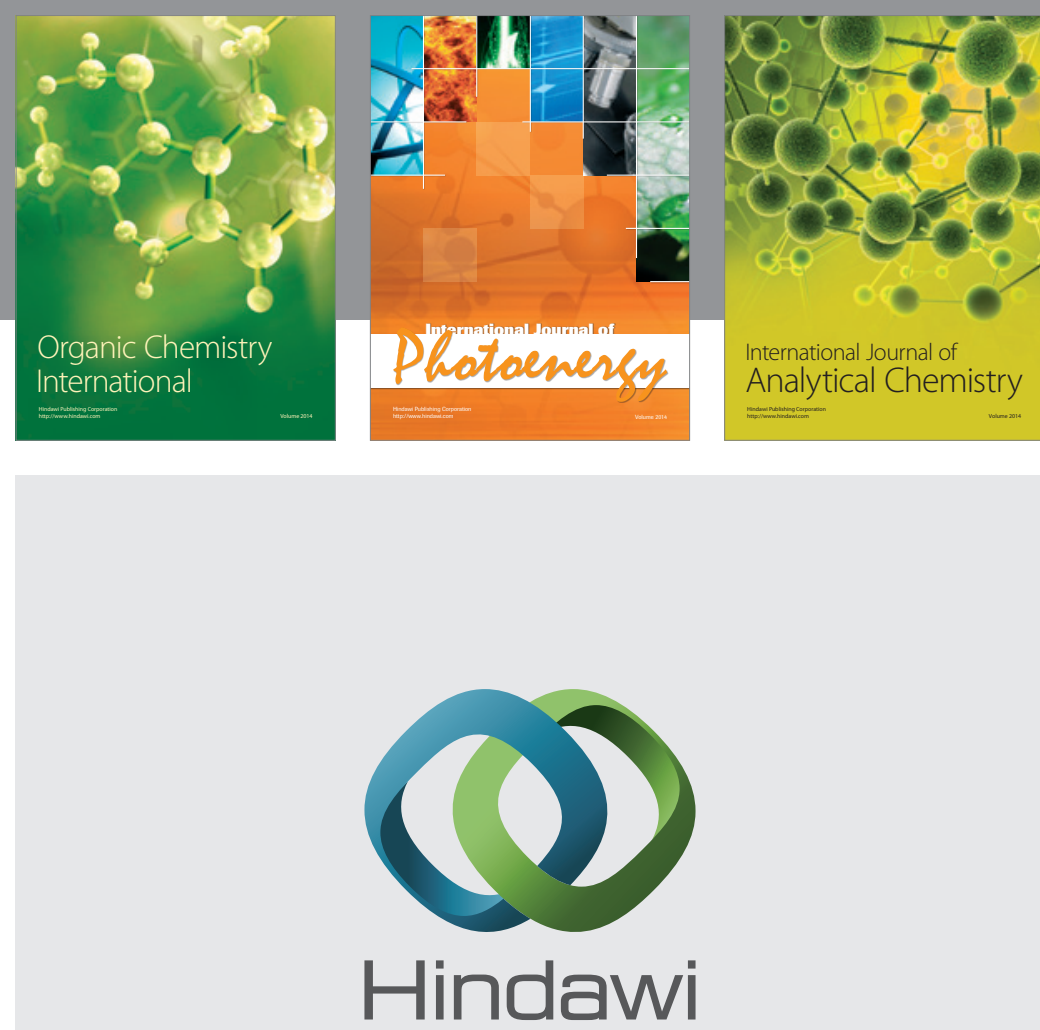

Submit your manuscripts at

http://www.hindawi.com
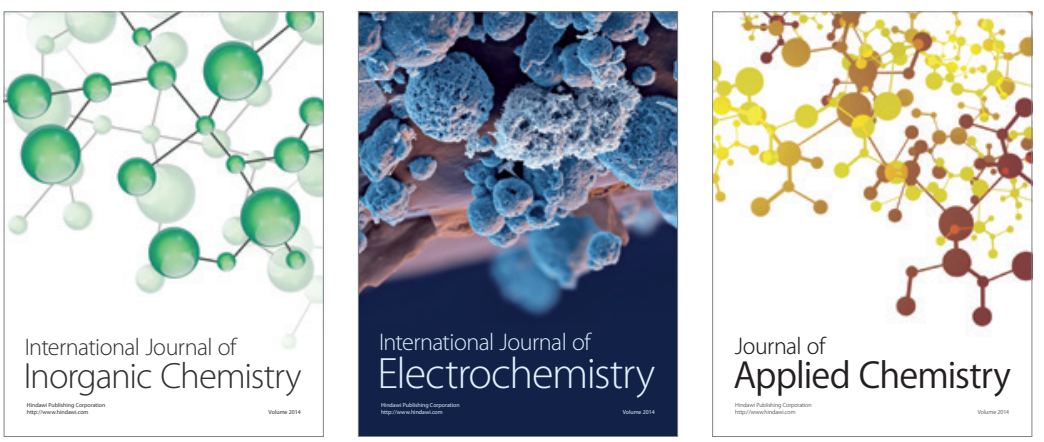

Journal of

Applied Chemistry
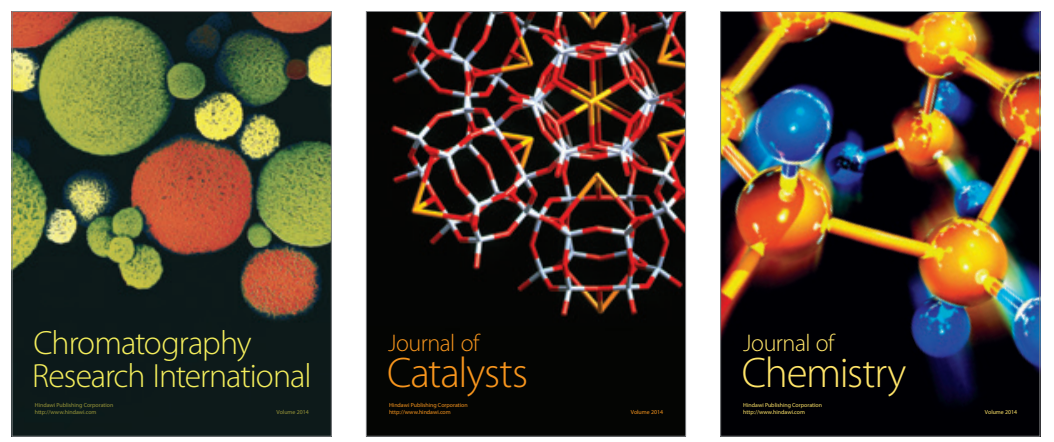
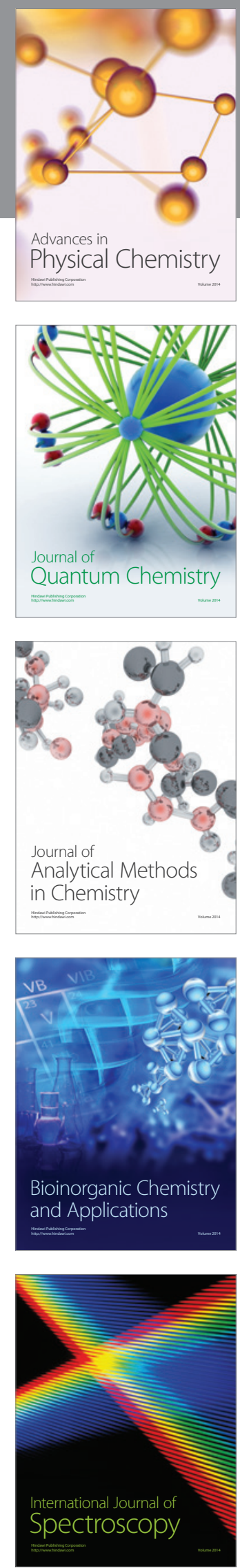